\title{
Land-use/Land-cover Changes and Deforestation in Effan Forest Reserve, Kwara State, Nigeria
}

\section{Adesoji A. Adeyemi, Farouq M. Owolabi}

Department of Forest Resources Management, Faculty of Agriculture, University of Ilorin, Ilorin, Nigeria

adeyemi.aa@unilorin.edu.ng, +2348032082627

\begin{abstract}
Remote sensing/GIS techniques are a versatile tool for $\mathrm{x}$-raying serial forest structural changes in retrospect. It would be impossible to evaluate past occurrences and changes in forest extents in past decades at Effan Forest Reserve without nonconventional means. Therefore, we adopted remote sensing technology using Landsat images to evaluate land-use change and degradation rates in the area with a view to ascertaining causal factors for possible minimization of forest degradation in Effan Forest Reserve. Land-use/land-cover changes were analyzed using USGS-Landsat TM and ETM images of 1987, 2002, 2014 and 2019. Field-data were collected using handheld GPS receiver and spatial statistical analyses were conducted using the ground control points (GCPs). For inventory data, a systematic sampling technique was adopted using ten $1.05 \mathrm{~km}$-transects at $500 \mathrm{~m}$ intervals. A total of 50 sample plots of $50 \times 50 \mathrm{~m}$ were used. All tree species with $\mathrm{Dbh} \geq 10 \mathrm{~cm}$ were enumerated. Nineteen tree species in ten families were encountered with Vitellaria paradoxa as the mostfrequently occurring species in the area. IUCN-listed endangered Pterocarpus erinaceus, hitherto abundant in the area, was rarely encountered during the survey, while Vitellaria paradoxa is gradually shrinking, going the relative abundance in the area. The result further showed that primary and secondary forests decreased considerably by 258.03 ha $(46.72 \%)$ and 9.18 ha $(3.63 \%)$, respectively, with a total forest loss of $50.3 \%$ in 32 years $\left(8.4\right.$ hayr $^{-1}, 1.6 \%$ per annum). While forest plantation size doubled by 369.72 ha within the period. This is worrisome as the remaining fragmented forests appeared to be on the decline, except the riparian vegetation, due to inaccessibility to the riparian by loggers. It thus appeared that forest protection approaches were ineffective. Increased protection efforts could save this forest reserve, and the concerned authority should consider a focused-enrichment planting involving indigenous species for ecosystem-repair.
\end{abstract}

Keywords:

Land-use change, forest conversion, species loss, fragmentation, deforestation

\section{Introduction}

Forests cover $31 \%$ of the earth's surface, as they produce vital oxygen and provide homes for people and wildlife [1]. It is no longer new that world's most threatened and endangered faunas live in forests, and about 1.6 billion people depend on those forests for food, fresh water, clothing, traditional medicine and shelter [2]. Forest 
habitats play a central role in the functioning of the biosphere, as the origins of many cultivated and domesticated plants and animals, just as tree components are very key to providing the frame on which other life forms depend $[3,4,5]$. The resources therein are renewable resources and also provide socio-economic benefits to individuals and communities. Nevertheless, tropical forests face growing threats of deforestation, which in most cases, is aided by forest degradation and fragmentation. Deforestation and forest degradation have caused severe decline in forest functions in recent times $[6,7]$.

Forest degradation is broadly defined as a reduction in the capacity of a forest to produce ecosystem services such as carbon storage and wood products due to anthropogenic factors and environmental changes [8]. The main causes of degradation vary globally, including unsustainable logging, poor agricultural practices, invasive species, fuel-wood gathering, livestock grazing, and wildfire with synergistic effects. The rate at which forest is disappearing is alarming and requires sustainable measures of utilization. This cannot be done without a good understanding of the dynamics of forest composition and coverage over time, as well the drivers of those changes. Deforestation appears to be on the decline in some countries [9]. Human activities and interference within the earth's ecosystem have resulted in a continuous degradation of the ecosystem, which are unhealthy for current and future survivals [10]. This together is reflective of changes in land uses with dire consequences on the environment.

Land-use change is a key driver of environmental changes that influences the basic resources of land, water and forest resources. This is worsened by continued growth in human population as well as consequential increases in demands for the earth's resources $[11,12]$. 
In Nigeria, urban development, industrialization, infrastructural development and forest degradation are fast changing land covers. According to Worku and Deribew [13], high rates of water, soil and air pollution are consequences of changing land-use and land-cover. Biodiversity is reduced when land is changed from a relativelyundisturbed state to more intensive uses like farming, overgrazing and logging. Landuse change due to deforestation in the tropics is a major contributor to $\mathrm{CO}_{2}$ emissions, which averaged between 0.5 and 2.7 rigatoni of carbon per year [14]. These changes alter ecosystem services and affect the ability of biological systems to support human needs.

The forest management objective for Effan Forest Reserve was to establish sustainable-level forest utilization, and as part of the $16.7 \%$ of total land area of the state, which were gazetted for protection of forest [15]. However, it is unclear how well this has been achieved, and a good knowledge of the tree species diversity in the reserve could be a pointer to successes thus far achieved. No concrete information is available on the current forest conditions, which is crucial to establishing a sustainable forest management for the reserve. In order to save the forest from total disappearance, a conservation measure needs to be established. Nevertheless, information required for this is scarce. Lack of forest monitoring data also hinders an appreciation of the rate of deforestation. Therefore, we assessed tree species diversity and change dynamics of the reserve while providing an update on deforestation in the reserve with a view to suggesting sustainable management strategies.

Good information on forest condition and the extent of forest degradation will enable the prioritization of human and financial resources to prevent further losses, and to explore possibilities for rehabilitating degraded forests [16]. Information on flora composition of a forest reserve is a key element that is required for necessary 
conservation measures to be put in place. In view of the foregoing, this study provides information on the plant species diversity in Effan Forest Reserve and baseline data on temporal vegetation changes.

\section{Materials and Methods}

\subsection{Study area}

Effan Forest Reserve is located in Edu Local Government Area of Kwara State, Nigeria. The reserve lies between longitudes $5^{\circ} 18^{\prime} 00^{\prime \prime} \mathrm{E}$ and $5^{\circ} 23^{\prime} \mathrm{E}$ and latitudes $8^{\circ} 47^{\prime} \mathrm{N}$ and $8^{\circ} 50^{\prime} \mathrm{N}$ (Fig. 1). The total area of the reserve is 1,458 ha which was originally acquired by government under the public lands ordinance of 1975 [17]. This consists of natural forest and plantation tree species.

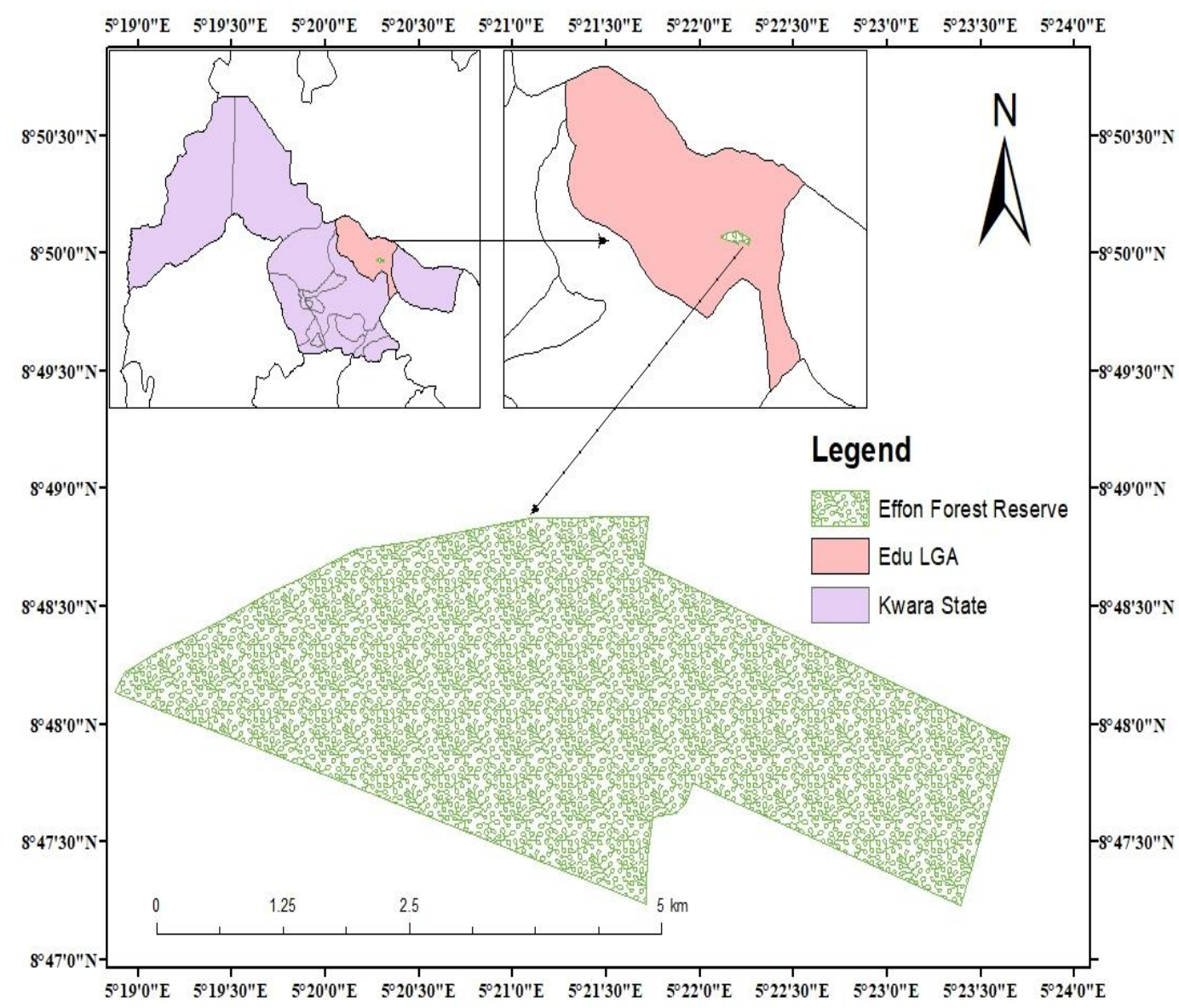

Figure 1. Map of the study area 
The area is characterized by tropical climate with two distinct seasons: wet (May - October) and dry (November - April). The length of the rainy season is over 180 days. The reserve vegetation falls within guinea savannah ecosystem with riparian forest along streams and swamps. The area comprises of different tree species like Vitellaria paradoxa, Prosopis africana, Acacia seyal, Parkia biglobosa, Daniella oliveri and Anogeisus leiocarpa. The study area is underlain by both Precambrian basement complex rock and the crustaceous sand storm of Bida basin [18] The soil is developed cretaceous sedimentary basement complex, which is sandy alluvium type predominantly shallow soil and low level of organic matter. Hydromorphic soils are dominant in the lowest part of the Effan Stream [17].

Effan Forest Reserve falls within the peneplain of the River Niger trough, which stretches from Jebba to Eggan on a topography that is relatively flat, lying near the River Niger and rises to the crystalline upland in the south to an elevation of less than $150 \mathrm{~m}$ above sea level [19]. The River Niger and its tributaries, Oyi and Oro, drain the land. An overflow of the Niger and its tributaries during rain often floods the area and on recess deposits sediments on the flood plain [20]. The location of Effan Forest Reserve is dominated by Nupe-speaking people. They live close to river banks and engage in agriculture as the major economic activity. Fish farming and rice cultivation are the two major activities of the people in the study area.

\subsection{Data sources}

For the flora data, systematic sampling technique was adopted for plot location. Ten (10) transects of $1.05 \mathrm{~km}$ long were used at $500 \mathrm{~m}$ intervals. On each transect five sample plots of $50 \times 50 \mathrm{~m}$ were laid at $200 \mathrm{~m}$ intervals. The number and scientific 
names of all the tree species with $\mathrm{Dbh} \geq 10 \mathrm{~cm}$ encountered in each sample plot were recorded. Individual tree structural variables including Dbh and total height were also measured in 2019 to compute basal area and stand density. A total of fifty sample plots were used for the study.

In addition, Landsat TM and ETM satellite images of the study area taken in January 1987, February 2002, December 2014 and January 2019 (with path/row of 190/54). In addition, cloud-free Landsat TM and ETM satellite images of the study area taken in January 1987, February 2002, December, 2014 and January 2019 (with path/row of 190/54 were downloaded from the USGS. Acquisition dates of the multitemporal datasets of different sensors TM and ETM scenes employed in the change detection process fall within the same season.

Landsat ETM 2019-satellite image, topographic maps and a GPS receiver were used to create random points to aid ground-truthing (site verification) of the land-use classes on the field. The geographic co-ordinates of the observation sites from the GPS reading were recorded, and the locations were indicated on the ETM image. These were used for verification of the different land-use types.

\subsection{Data Analysis}

Species diversity was computed using Shannon-Wiener's and Simpson's Diversity indices as:

Shannon-Wiener's index

$H^{\prime}=-\sum_{t=1}^{S} P_{i} \ln \left(P_{i}\right)$

Where; $S=$ total number of species in the community, $P_{i}=$ proportion of $\mathrm{S}$ made up of the $i$ th species, $\ln =$ natural logarithm. 
Simpson's diversity index

$D=1-\frac{\sum n(n-1)}{N(N-1)}$

Where; $\mathrm{n}=$ total number of a particular species, $\mathrm{N}=$ total number of trees of all species.

Equitability index

$J=\frac{H^{\prime}}{\log (S)}$

Species relative abundance $(R A)$

$R A(\%)=\left(\frac{n i}{N}\right) \times 100$

Where; $\mathrm{N}=$ total number of individuals in the sampled area, ni $=$ number of individuals of a given species.

The species richness in the area was computed using Margalef's Index of species richness [21]

$d=\frac{S}{\sqrt{N}}$

Where; $\mathrm{S}=$ the number of species encountered, $\mathrm{N}=$ the total number of individuals of all the tree species. 


\subsection{Image processing and analysis}

The Landsat images were level-1 products, implying that they were already corrected for radiometric, atmospheric (including cloud patching) and noise errors by the data provider. However, to maximize the use of all spectral information contained in the satellite images, all forms of atmospheric effects caused by scattering and absorption from the earth surface radiation as at the time of acquisition were removed in the course of image pre-processing in ArcGIS 10.5 and Landsat Toolbox for necessary corrections and quality improvements. For each of the Landsat images, band combination was done to form a single multi-spectral image. For example, bands 5 (mid-IR): $1.55-1.75 \mu \mathrm{m}, 4$ (NIR): $0.76-0.90 \mu \mathrm{m}$ and 3 (red): 0.63-0.69 $\mu \mathrm{m}$ were combined (stacked together) to form a single multi-spectral image dataset using the following the standard image processing steps in ArcGIS 10.5 with appropriate ArcGIS 10.5 extensions. After the images were geo-referenced, mosaicked and subset on the basis of region of interest (ROI), satellite data were studied by assigning perpixel signatures and differentiating the land area into four classes on the bases of the specific Digital Number (DN) value of different land-use classes. Unsupervised classification was adopted for its ability to distinguish minimal differences in spectral signature, which was very difficult using supervised classification, maximum likelihood method. Two satellite sensors (Landsat 5 TM for 1987 and 2002 with bandcombination order of 5,4,3 and Landsat 7 ETM+ for 2014 and 2019 with bandcombination order of $4,5,3$ ) having the same spatial resolution of $30 \mathrm{~m}$ were used. These band combinations are also called the near infrared (NIR) composite. It uses near-infrared (5), red (4) and green (3). Because chlorophyll reflects near infrared light, this band composition is useful for analyzing vegetation. In particular, areas in red have better vegetation health. Using the Landsat image bands, false colour 
composites, preliminary land-cover maps were obtained with 20 classes in order to capture all variations in land-use and land-cover strata. Hand-held GPS Receiver was used to collect up to 100 spatial locations within each of the land-cover/land-use categories during ground-truthing. A total of 400 GCPs were collected in 2019 and used for final LULC classification. After overlaying the GPS points on the preliminary images to verify the true land-use or cover types, the entire images of the four data periods (i.e. 1987, 2002, 2014 and 2019) were then reclassified into four classes based on the spectral signatures, field verification data and the guidance of local experts (forestry staff and traditional chiefs).

The delineated classes were primary forest, secondary forest, (forest) plantation and farmland. Each class was given unique identity and assigned a particular color to make them separate from each other. To improve classification accuracy and reduction of misclassifications, post-classification refinement was used for simplicity and effectiveness of the method according to Harris and Ventura [22]. The problems of mixed pixels were addressed by visual interpretation of affected $1.7 \%$ of the total pixels in the entire images of the area. For the enhancement of classification accuracy and quality of the land-use maps produced, visual interpretation was very important. Thus, local knowledge, reference data, as well as visual analysis, considerably improved the results obtained using the unsupervised classification.

\subsection{Change detection}

The first step in change detection was raster to vector conversion to enable discriminations of various pixels and the change from one land-use to another since all the images used were cloud-free, and with reduced noise, which might result in 
changes of pixel classes, or that from differences in sensors, following this procedure in the ArcGIS 10.5 environment:

- In Arctool Box, select 'Conversion Tools',

- choose 'From Raster' and select 'Raster to Polygon',

- click on 'Input Raster' (i.e. include class in the attribute table of the raster data) to select the class created in the raster,

- then click on 'Ok' to complete this stage.

The second step involved dissolution of the vector data (polygons). This was done following the steps:

- On the menu bar, select 'Geoprocessing' and click on 'Dissolve' (this was done for the 1987, 2002, 2014 and 2019 images separately),

- click on 'Input feature class' (i.e. select the vector file to be dissolved), then click 'Ok' and allowed the process to run through to completion.

The third step involved the unification of the four datasets (i.e. 1987, 2002, 2014 and 2019 images), as follows:

- Select 'Geoprocessing', then click 'Union', andinput feature class (i.e. by selecting the four dissolved vector files for 1987, 2002, 2014 and 2019) and click 'Ok' to complete the process.

Finally, open the attribute table of the unified vector (shapefile), and add another field (i.e. Area), followed by right-clicking on the field, then clicked on 'Calculate Geometry' then clicked 'Yes', after which the unit is changed to hectare. This is followed by clicking on 'Ok', then 'Yes'.

The next stage is to export the attribute table by clicking on 'Export the attribute table', followed by 'Table Options', then 'Export', and the file extension is changed to dBASE Table, followed by 'Save', then click 'OK' and 'No' to complete the 
process. The probable changes in pixel classes due to noise effects were resolved using spatial analyst tools in ArcGIS 10.5 and Landsat Toolbox (in this case, only scan lines were removed since there were no other noise or error).

\section{Accuracy assessment}

The overall accuracy land-use/land-cover classification was done by creating a confusion matrix in ArcMap 10.5 using ground reference points obtained during ground-truthing, and following these steps:

- From 'Spatial Analyst Tools', select 'Extraction', click on 'Extract Multi Values to Points'

- then click on 'Input point features' (input the Ground-truth GPS points collected on the field),

- click 'Input raster' (input the classified raster), then 'Ok' and 'done'.

- The attribute table is then exported (in dBASE format) for further analysis of the confusion matrix to determine the classification accuracy and Kappa Coefficient. A total of 450 ground-truthed points (locations) were used for accuracy assessment of the land-use/land-cover classification. A total of 450 points were also created in the classified image of the study area to generate the cell array for confusion matrix table. It was computed by dividing the total correctly-classified pixels by the total number of pixels in the confusion matrix as adopted previous workers [23,24,25,26]. Overall classification accuracy determined by:

$Y=\frac{\sum_{i=1}^{n} x_{i}}{\sum_{j=1}^{N} x_{j}} \times 100$ 
Where;

$\sum_{i=1}^{n} x_{i}=$ sum of the correct points; $x_{j}=\sum_{j=1}^{N} x_{i}=$ total number of all points.

Other statistics used for accuracy assessment included sensitivity (producer's accuracy), specificity, commission error, omission error, users' accuracy and Kappa's coefficient $(\mathrm{K})$ as given in the subsequent lines.

Producer's Accuracy $=\frac{w}{w+z}$

User's Accuracy $=\frac{y}{y+z}$

Specificity $=\frac{z}{x+z}$

Commission Error $=1-$ Specificity.

Ommission Error $=1-$ Produccer's accuracy.

Where, $\mathrm{w}=$ number of times a classification agreed with the observed value, $\mathrm{x}=$ number of times a point was wrongly classified; $\mathrm{y}=$ number of times a point was not classified as ' $A$ ' when it was not observed to be 'A'; $\mathrm{z}=$ number of times a point was classified as 'A' when it was observed to not be 'A'. Kappa's coefficient measures perfect agreement between prediction and reality or classification results and the real observation, as is the case in this study. It was computed as:

$$
K=\frac{N \sum_{i j=1}^{r} x_{i j}-\sum_{i j=1}^{r}\left(x_{i j}+X x_{+i}\right)}{N^{2}-\sum_{i j=1}^{r}\left(x_{i j} X x_{+j}\right)}
$$


Where, $r=$ number of rows and columns in error matrix; $N=$ total number of observations (pixels); $x_{i j}=$ observations in the ith row and jth column; $x_{+i}=$ marginal total of the ith row; $x_{+j}=$ marginal total of the jth column .

Kappa Coefficient ranges between 0 and 1. A Kappa coefficient of 1 implies perfect agreement, while any value nearing zero means that the agreement between prediction and reality or between classification and real observation is no better than that due to chance. Kappa statistic is categorized as reproduced by Rwanga and Ndambuki (2017).

\subsection{Trend analysis}

This was done to get the rate of change of the area over (area covered or area in which changes occur over the period of time for the study).

Trend Analysis: $\triangle L U L C=L_{2}-L_{1}$

$\mathrm{L}_{2}=$ final year; $\mathrm{L}_{1}=$ initial year;

Rate of Change $=\left(\frac{\left(L_{2}-L_{1}\right)}{\mathrm{t}}\right) \times 100$

$\mathrm{t}=$ time $; \mathrm{L}_{2}=$ final year; $\mathrm{L}_{1}=$ initial year

\subsection{Vegetation index}

The Normalised Difference Vegetation Index (NDVI) is one of the oldest, wellknown, and most-frequently used VI. The combination of its normalized difference formulation, use of the highest absorption and reflectance regions of chlorophyll make it robust over a wide range of conditions. It was computed as: 


$$
\mathrm{NDVI}=\frac{\rho_{\mathrm{NIR}}-\rho_{R E D}}{\rho_{N I R}+\rho_{R E D}}
$$

Where; $\rho_{N I R}$ and $\rho_{R E D}$ represent the reflectance at near infrared and red wavelength bands, respectively. Although NDVI values range between -1 and 1 , the common range for green vegetation is 0.2 to 0.8 . The NDVI was used to measure changes in green vegetation.

\section{Results}

\subsection{Tree species diversity}

A total of 19 tree species belonging to 10 families were recorded in the area. Members of the family Fabaceae were the most frequently encountered family in the area with 8 tree species, followed by the family Combretaceae with 3 species. A total of 105 trees/ha with $\mathrm{Dbh} \geq 10 \mathrm{~cm}$ were recorded in the area of study (Table 1). Of the 19 tree species encountered, only Vitellaria paradoxa C.F. Gaerth (last assessed by IUCN in 1998) and Pterocarpus erinaceus Poir are vulnerable and endangered according to the IUCN Red List. However, on national and regional scales, Vitellaria paradoxa, Vitex doniana Sw, Lophira lanceolata Tiegh. Ex Keay and Nauclea latifolia Smith have been considered endangered due to over-exploitation, low regeneration and very poor viability. Other species like Parkia biglobosa (Jacq.) R.Br. ex G. Don, Pericopsis laxiflora (Benth.) Van Meeuwen, Prosopis africana Guill. \& Perr. and Terminalia glaucescens Planch. Ex Benth. are threatened by habitat losses.

Details of descriptive statistics for tree structural variables are shown in Table 2. 
Table 1: Tree species present in Effan Forest Reserve

\begin{tabular}{|c|c|c|c|c|c|}
\hline SN & Species & Family & Tree /ha & RD (\%) & $\begin{array}{l}\text { IUCN } \\
\text { status }\end{array}$ \\
\hline 1 & Acacia seyal Delile & Fabaceae & 2 & 1.8 & $\mathrm{NE}$ \\
\hline 2 & Anogeissus leiocarpa (DC.) Guill. \& Perr. & Combretaceae & 4 & 4.3 & $\mathrm{LC}$ \\
\hline 3 & Azadirachta indica Juss. & Meliaceae & 2 & 1.9 & $\mathrm{LC}$ \\
\hline 4 & Combretum molle R. Br. Ex G. Don & Combretaceae & 3 & 2.8 & $\mathrm{LC}$ \\
\hline 5 & Daniellia oliveri Benn. & Fabaceae & 7 & 6.5 & $\mathrm{LC}$ \\
\hline 6 & Detarium macrocarpum Guill. \& Perr. & Fabaceae & 2 & 1.8 & $\mathrm{NE}$ \\
\hline 7 & Ficus capensis Forssk. & Moraceae & 1 & 0.9 & $\mathrm{NE}$ \\
\hline 8 & Gmelina arborea Roxb. & Lamiaceae & 37 & 35.4 & $\mathrm{LC}$ \\
\hline 9 & Hymenocardia acida Tul. & Phyllathaceae & 2 & 1.5 & $\mathrm{LC}$ \\
\hline 10 & Lophira lanceolata Tiegh. Ex Keay & Ochnnaceae & 8 & 7.3 & $\mathrm{LC}$ \\
\hline 11 & Nauclea latifolia Smith & Rubiaceae & 3 & 3.2 & $\mathrm{LC}$ \\
\hline 12 & Parkia biglobosa R.Br. ex G. Don & Fabaceae & 5 & 4.8 & $\mathrm{LC}$ \\
\hline 13 & Pericopsis laxiflora (Benth.) Van Meeuwen & Fabaceae & 1 & 1.2 & $\mathrm{LC}$ \\
\hline 14 & Piliostigma thonningii (Schum.) Milne-Redh & Fabaceae & 6 & 5.9 & $\mathrm{NE}$ \\
\hline 15 & Prosopis africana Guill. \& Perr. & Fabaceae & 4 & 3.5 & $\mathrm{LC}$ \\
\hline 16 & Pterocarpus erinaceus Poir. & Fabaceae & 2 & 2.2 & EN \\
\hline 17 & Terminalia glaucescens Planch. Ex Benth. & Combretaceae & 2 & 1.8 & $\mathrm{LC}$ \\
\hline 18 & Vitellaria paradoxa C.F. Gaerth & Sapotaceae & 11 & 10.4 & VU \\
\hline 19 & Vitex doniana $\mathrm{Sw}$ & Verbenaceae & 3 & 2.8 & $\mathrm{LC}$ \\
\hline Total & & & 105 & 100 & \\
\hline
\end{tabular}

N.B.: NE- not evaluated, LC - least concern, EN - endangered, VU - vulnerable, 
Table 2: Descriptive statistics for the individual tree growth variables

\begin{tabular}{|c|c|c|c|c|}
\hline Species & Family & Structural variable & Mean & SD \\
\hline \multirow[t]{4}{*}{ Acacia seyal Delile } & Fabaceae & Dbh $(\mathrm{cm})$ & 28.80 & 9.97 \\
\hline & & $\mathrm{Ht}(\mathrm{m})$ & 6.50 & 1.91 \\
\hline & & $\mathrm{BA}\left(\mathrm{m}^{2}\right)$ & 0.07 & 0.05 \\
\hline & & $\mathrm{N}$ (ha) & 2 & - \\
\hline \multirow[t]{4}{*}{ Anogeissus leiocarpa (DC.) Guill. \& Perr. } & Combretaceae & Dbh $(\mathrm{cm})$ & 31.83 & 9.40 \\
\hline & & $\mathrm{Ht}(\mathrm{m})$ & 8.70 & 2.21 \\
\hline & & $\mathrm{BA}\left(\mathrm{m}^{2}\right)$ & 0.08 & 0.03 \\
\hline & & N (ha) & 4 & - \\
\hline \multirow[t]{4}{*}{ Azadirachta indica Juss. } & Meliaceae & Dbh $(\mathrm{cm})$ & 24.14 & 8.82 \\
\hline & & $\mathrm{Ht}(\mathrm{m})$ & 8.81 & 2.64 \\
\hline & & $\mathrm{BA}\left(\mathrm{m}^{2}\right)$ & 0.05 & 0.04 \\
\hline & & N (ha) & 2 & - \\
\hline \multirow[t]{4}{*}{ Combretum molle R. Br. Ex G. Don } & Combretaceae & Dbh $(\mathrm{cm})$ & 33.92 & 18.50 \\
\hline & & Ht (m) & 8.80 & 3.70 \\
\hline & & $\mathrm{BA}\left(\mathrm{m}^{2}\right)$ & 0.12 & 0.14 \\
\hline & & $\mathrm{N}$ (ha) & 3 & - \\
\hline \multirow[t]{4}{*}{ Daniellia oliveri Benn } & Fabaceae & $\operatorname{Dbh}(\mathrm{cm})$ & 43.11 & 23.71 \\
\hline & & $\mathrm{Ht}(\mathrm{m})$ & 6.80 & 3.10 \\
\hline & & $\mathrm{BA}\left(\mathrm{m}^{2}\right)$ & 0.23 & 0.01 \\
\hline & & N (ha) & 7 & - \\
\hline \multirow[t]{4}{*}{ Detarium macrocarpum Guill. \& Perr. } & Fabaceae & Dbh $(\mathrm{cm})$ & 26.30 & 9.85 \\
\hline & & $\mathrm{Ht}(\mathrm{m})$ & 5.30 & 0.87 \\
\hline & & $\mathrm{BA}\left(\mathrm{m}^{2}\right)$ & 0.06 & 0.04 \\
\hline & & $\mathrm{N}$ (ha) & 2 & - \\
\hline \multirow[t]{4}{*}{ Ficus capensis Forssk. } & Moraceae & Dbh $(\mathrm{cm})$ & 21.75 & 9.45 \\
\hline & & $\mathrm{Ht}(\mathrm{m})$ & 7.02 & 2.38 \\
\hline & & $\mathrm{BA}\left(\mathrm{m}^{2}\right)$ & 0.05 & 0.05 \\
\hline & & $\mathrm{N}$ (ha) & 1 & - \\
\hline Gmelina arborea Roxb. & Lamiaceae & Dbh $(\mathrm{cm})$ & 15.27 & 3.99 \\
\hline
\end{tabular}




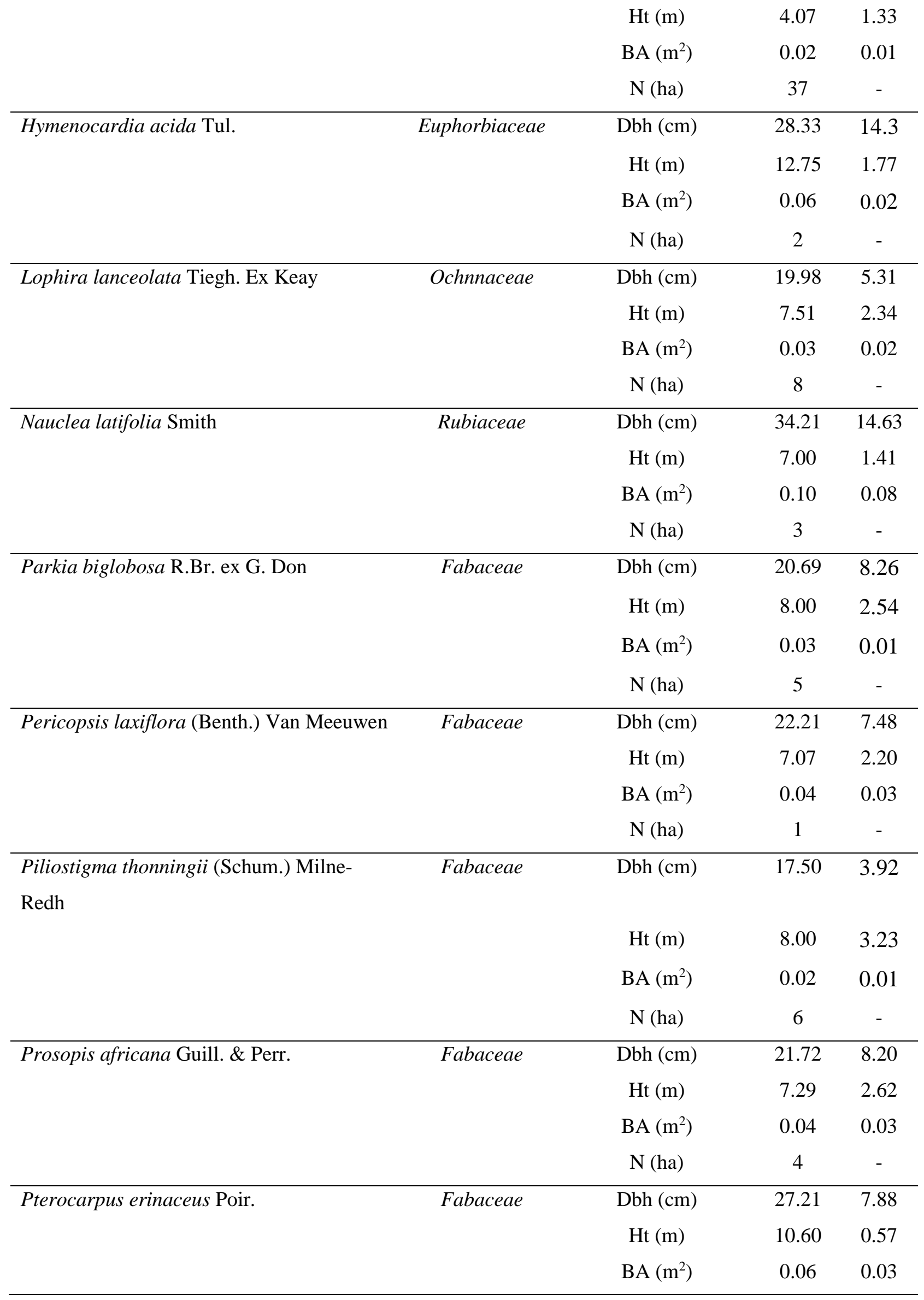




\begin{tabular}{lcccc}
\hline & & $\mathrm{N}(\mathrm{ha})$ & 2 & - \\
\hline Terminalia glaucescens Planch. Ex Benth. & Combretaceae & Dbh $(\mathrm{cm})$ & 28.3 & 6.62 \\
& & $\mathrm{Ht}(\mathrm{m})$ & 12.46 & 1.70 \\
& & $\mathrm{BA}\left(\mathrm{m}^{2}\right)$ & 0.12 & 0.26 \\
\hline Vitellaria paradoxa C.F. Gaerth & $\mathrm{N}(\mathrm{ha})$ & 2 & - \\
\hline Sitex doniana Sw & & Dbh (cm) & 28.15 & 4.51 \\
& & & & \\
& & $\mathrm{Ht}(\mathrm{m})$ & 13.27 & 2.65 \\
& Verbenaceae & $\mathrm{BA}\left(\mathrm{m}^{2}\right)$ & 1.87 & 0.42 \\
& & $\mathrm{~N}(\mathrm{ha})$ & 11 & - \\
\hline & & $\mathrm{Hbh}(\mathrm{cm})$ & 26.80 & 9.13 \\
& & $\mathrm{Ht}(\mathrm{m})$ & 8.53 & 1.74 \\
& & $\mathrm{NA}\left(\mathrm{m}^{2}\right)$ & 1.19 & 0.87 \\
\hline
\end{tabular}

\subsection{LULC classes of Effan Forest Reserve}

The classification of the images yielded the four land use types used in describing the area of study. The result revealed that primary forest covered a total of 552.15 ha (37.9\%) in 1987, with more concentration along the Effan River and in the middle zone of the reserve. Plantation (forest plantation consisting mainly of Gmelina arborea) covered a total of 369.81 ha $(25.4 \%)$ of the area with farmland covering 283.59 ha $(19.4 \%)$ of the reserved area. The rarest of the land-use types at the time was secondary forest covering a total of 252.99 ha (17.3\%). Between 1987 and 2002, primary forest lost $23.6 \%$ of its size (552.15 ha), and reduced to 421.65 ha (which was $28.9 \%$ of the total land area). Secondary forest, however, increased by $38 \%$ to 349.11 ha (representing $23.9 \%$ of the total land area) within the period (1987-2002). Plantation also increased to 519.12 ha (addition of 40.4\%). Farmland contrasted by $59.5 \%$ to 168.66 ha covering $11.6 \%$ of the reserve. 
In 2014 , the result showed that primary forest further decreased by $40.4 \%$ to 251.10 ha in twelve years. Similarly, plantation lost $7.8 \%$ of its size in 2002 to occupy a total of 478.80 ha. Secondary forest, however, increased by $21.8 \%$ to 425.07 ha. Farmland also increased by $78 \%$ between 2002 and 2014 to 303.57 ha (amounting to $20.8 \%$ of the reserve area). In 2019 , plantation occupied 739.53 ha $(50.7 \%)$ with primary forest, secondary forest and farmland covering 294.12 ha (20.2\%), 243.81 ha (16.7\%) and 181.08 ha (12.4\%), respectively (Fig. 2 and Table 3). On the whole, primary and secondary forests decreased by 46.72 and $3.6 \%$ (total natural forest loss of $50.3 \%$ ) between 1987 and 2019, while plantation increased by $99.97 \%$ within the same period. Farmland steadily declined between 1987 and 2002 with a spike in 2014, this sharply contrasted in 2019 resulting in a decline of up to $36.1 \%$ for the assessment period (1987-2019).

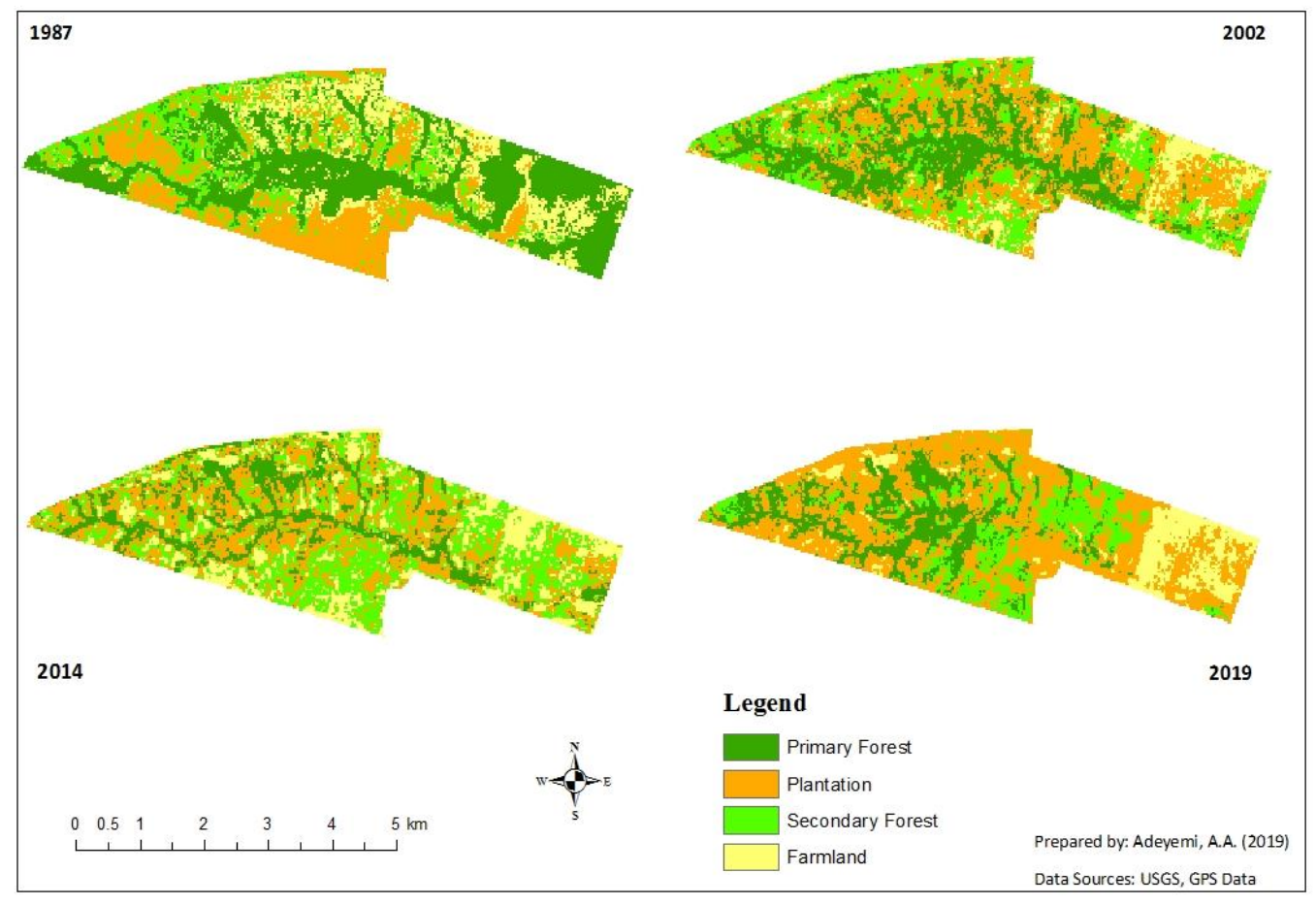

Figure 2. LULC classes of Effan Forest Reserve between 1987 and 2019 
Table 3: Spatial extents of land-use/land-cover types between 1987 and 2019

\begin{tabular}{lcccccccc}
\hline Year & \multicolumn{2}{c}{$\mathbf{1 9 8 7}$} & \multicolumn{2}{c}{$\mathbf{2 0 0 2}$} & \multicolumn{2}{c}{$\mathbf{2 0 1 4}$} & \multicolumn{2}{c}{$\mathbf{2 0 1 9}$} \\
\hline LULC & Area (ha) & $\%$ & Area (ha) & $\%$ & Area (ha) & $\%$ & Area (ha) & $\%$ \\
\hline Primary forest & 552.15 & 37.9 & 421.65 & 28.9 & 251.1 & 17.2 & 294.12 & 20.2 \\
Secondary forest & 252.99 & 17.3 & 349.11 & 23.9 & 425.07 & 29.1 & 243.81 & 16.7 \\
Plantation & 369.81 & 25.4 & 519.12 & 35.6 & 478.8 & 32.9 & 739.53 & 50.7 \\
Farmland & 283.59 & 19.4 & 168.66 & 11.6 & 303.57 & 20.8 & 181.08 & 12.4 \\
\hline Total & 1458.54 & 100 & 1458.54 & 100 & 1458.54 & 100 & 1458.54 & 100 \\
\hline
\end{tabular}

Table 4 presents the land-use and land-cover (LULC) change trend of the reserve over the last 32 years. The result showed that the four land-use types changed tremendously within the period. Between 1987 and 2019, primary forest decreased by 258.03 ha, while secondary forest shrank by 9.18 ha. However, plantation increased by 369.72 ha.

Table 4: LULC change trend between 1987 and 2019

\begin{tabular}{lcccc}
\hline Year & $\mathbf{1 9 8 7 - 2 0 0 2}$ & $\mathbf{2 0 0 2 - 2 0 1 4}$ & $\mathbf{2 0 1 4 - 2 0 1 9}$ & $\mathbf{1 9 8 7 - 2 0 1 9}$ \\
\hline Primary forest (ha) & -130.5 & -170.55 & 43.02 & -258.03 \\
Plantation (ha) & 149.31 & -40.32 & 260.73 & 369.72 \\
Secondary forest (ha) & 96.12 & 75.96 & -181.26 & -9.18 \\
Farmland (ha) & -114.93 & 134.91 & -122.49 & -102.51 \\
\end{tabular}

N.B.: $-v e=$ decline $;+v e=$ increase, between two periods

Table 5 presents the LULC classification accuracy results. The overall accuracy was $88.1 \%$. Producer's accuracies ranged between 0.9265 and 0.9513 while user's 
accuracies, which reflect the reliabilities of the classification to the user, were between 0.7163 and 0.8911 . The overall Kappa's coefficient was $0.86 \%$.

Table 5: Classification accuracy assessment results for LULC

\begin{tabular}{lllllll}
\hline LULC class & \multicolumn{5}{c}{ Category-wise accuracy statistics } \\
\cline { 2 - 7 } & Specificity & CE & OE & UA & PA & K \\
\hline Primary forest & 0.8985 & 0.1015 & 0.0487 & 0.7163 & 0.9513 & 0.8513 \\
Plantation & 0.9364 & 0.0636 & 0.0705 & 0.7902 & 0.9295 & 0.8602 \\
Secondary forest & 0.9265 & 0.0735 & 0.0537 & 0.8911 & 0.9463 & 0.8867 \\
Farmland & 0.9346 & 0.0654 & 0.0735 & 0.7830 & 0.9265 & 0.8369 \\
Mean & $\mathbf{0 . 9 2 4}$ & $\mathbf{0 . 0 7 6}$ & $\mathbf{0 . 0 6 1 6}$ & $\mathbf{0 . 7 9 5 2}$ & $\mathbf{0 . 9 3 8 4}$ & $\mathbf{0 . 8 5 8 8}$ \\
\hline
\end{tabular}

NB: CE - commission error; OE - omission error; UA - user's accuracy; $P A$ - producer's accuracy, $K=$ Kappa's coefficient

The results of the NDVI for the study area between 1987 and 2019 are shown in Fig. 3. The values ranged from as low as 0.0510 in 2019 to as high as 0.44385 in 2002, indicating that vegetation was healthier in that year compared to other periods studied. This also means that more healthy natural forests in the area disappeared in later years, up to 2019. 

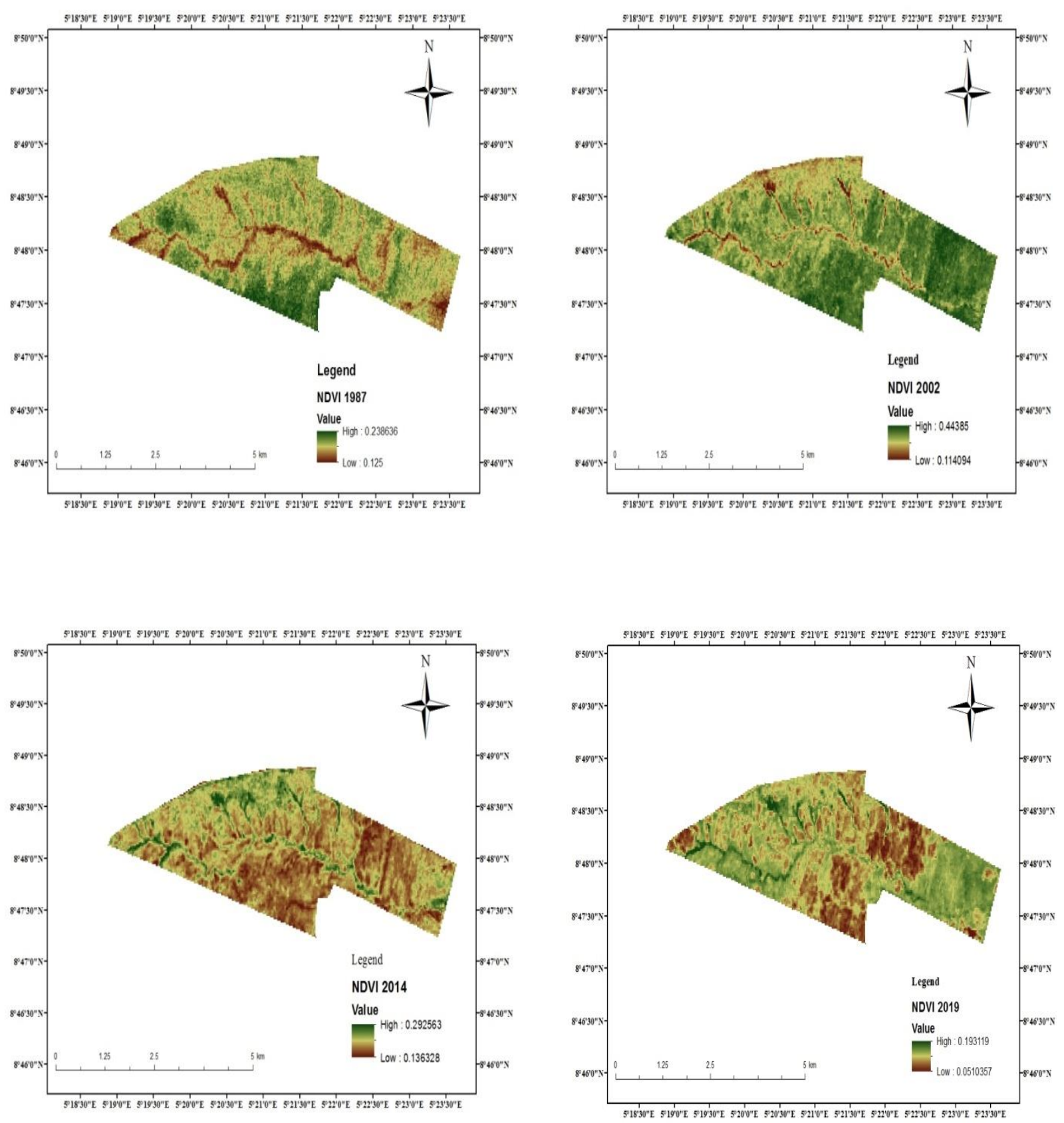

Fig. 3: NDVI of 1987, 2002, 2014 and 2019 


\section{Discussion}

The nineteen (19) tree species recorded in the area with very few individual tree species of conservation importance showed that natural forest conversion especially to monoculture forest plantation (of Gmelina arborea) severely impacted on indigenous tree species composition, and encouraged biodiversity losses. Meanwhile, the area was constituted into reserve due to its unique nature with appreciable concentration of valuable indigenous species (e.g. Ficus mucuso, Blighia sapida, Bridelia micrantha, Dialium guineense, Khaya senegalensis, Khaya ivorensis and Pterocarpus soyauxii in the early 1980s). According to Kwara State Ministry of Environment and Forestry [15], only two (Pterocarpus erinaceus and Vitellaria paradoxa) of these locallyimportant species (used for medical and food purposes respectively) were encountered. Most part of the area, particularly the central and eastern axes, where those species were perceived to occur have been converted to either monoculture plantation (of only Gmelina arborea stands) or agricultural land, which may have serious ecological implication and consequences, especially on stability of the forest ecosystem, since stability of plant communities are usually more sensitive to biodiversity losses [27]. It has been observed that, to maintain ecosystem function, it is not only important to conserve all sets of species therein, but also to protect the most sensitive species that are susceptible to ecosystem disturbance [28].

The abundance of a single species has also been observed to affect plant community and ecosystem properties, productivity [29] and species interactions. Although, most state governments in Nigeria intended to establish forest plantations through Taungya farming, which could marry forest regeneration with cultivation of arable crops, most of the project failed due to problems ranging from shortages of 
funds, lack of commitments on the parts of farmers as well as political encumbrances. This has led to the then Taungya farmers taking over forest lands without due considerations to tree components to date [30], especially in the southern and central parts of Nigeria. Isese [31] noted that failure of this form of agroforestry was due to lack of fund after degraded forest lands were committed to Taungya farming. Hence, only agricultural component of the system thrived in most areas, and this has resulted in losses of valuable tree species in most part of the country, as evident in this study. Our finding is also in line with the position of Anyanwu et al. [32] who implicated farming as a primary cause of deforestation and biodiversity losses in Anambra State, south Nigeria.

The location of the forest reserve, being rural, implies local community attachment for livelihood activities [33]. Consequently, the conversion may have even had negative impacts on the economy and survival of the surrounding rural communities, whose livelihoods are, somehow, tied to the existence of the natural forest since most of the people living in the rural communities around the reserve source some non-timber forest products from the reserve, just as rightly noted by WWF [34], that over 60 million indigenous people depend on natural forest for their livelihoods, and this set of people are greatly impacted by any form of forest conversion. For this category of forest-dependent people, there are no ready-made alternatives to benefits hitherto derived from the reserve of natural constituents.

Tree species recorded in Effan Forest Reserve was lower than the 46 tree species reported by Suleiman et al. [35] on a more impactful land-use but similar vegetation with infrastructural development and approved areas for agriculture. Ordinarily the area should be of lesser diversity compared to what currently obtains in Effan Forest Reserve. Although the area was about 1,613 ha in extent, it is ridiculous that a 
gazetted reserve like Effan Forest Reserve should contain such fewer species recorded in this study except, perhaps, due to inadequate protection resulting from poor law enforcement. This may indicate a poor protection methods and compromise on the part of forest law enforcement agents, who are responsible for forest management, going by the trend observed in land uses, cover changes and the increases in deforestation rates with corresponding biodiversity losses in the reserve. Although we could not further substantiate some unauthorized exploitations in the reserve, which may have contributed to species losses, our experiences during data collection showed that timbers and wood for charcoal were being exploited despite the ban on such in the state. This is consistent with the report of WWF [34] that itemized poor governance and weak recognition of traditional tenure right as the key driving forces for forest conversion. There also pressures from overgrazing by cattle herders. FAO [36] has reported that growing demand for agricultural products to satisfy industry and geometrically increasing global population result in pressure on land and aided deforestation as this is majorly shaped by corruption.

Although the (state number) tree species encountered in this study were more that the 16 tree species reported by Akinsanmi and Akintunde [37] in Agba Forest Reserve. The geographic location of the former may have aided its over-exploitation, due to its proximity to rural communities, whose livelihoods largely depend on availability of some forest resources, especially non-timber forest products (NTFPs).The reduced tree diversity in the forest reserve is a result of rapid destruction of the primary forest in the forest reserve. The forest has been utterly fragmented and degraded in the last few years. This was due to conversion to non-forest land uses and unsustainable charcoal production, as observed during fieldwork. Fabaceae was the 
most represented family in the area. This is similar to what was reported by Suleiman et al. [35].

The predominance of this family may be due to their efficient seed dispersal mechanism. Most members of Fabaceae found in the tropics are wind-dispersed, and may account for their widespread occurrence in favourable conditions. This may also be attributed to close geographical characteristics with similar ecological distribution as the area studied by the previous workers. However the finding is not in agreement with Ikyaagba [38], who reported Combretaceae and Euphorbiaceae as the most represented families in similar ecosystem of geographic north-central of Nigeria. The dominance of Gmelina arborea can be related to a deliberate attempt to exterminate the primary forest with the believe that the use of rapidly-growing exotic species could replace the benefits offered by natural forest at shorter time without considering the fact that most indigenous tree species could yield even better within the same length of time under the same growing conditions and treatments. The result showed that throughout the 32 years studied, there was consistent reduction in natural forest covers to the tune of $50.3 \%$ of what they were in 1987 , with an increase in forest plantation of up to $100 \%$. The key causes of forest depletion in the area were mainly logging (illegal timber exploitation), over-grazing of cattle by herdsmen, who cut down trees to feed their animals during shortages of tall grasses in dryer parts of the year as well as pressure from land conversion for agricultural purposes and plantations of exotic tree species. This is consistent with the findings of Fasona et al. [39], Duguma et al. [40] and Wajim [41], who reported negative impacts illegal timber exploitation, forest conversion and over-grazing as major drivers of deforestation and forest degradation. Although, it is believed that forest plantation establishment provides a good measure of forest enrichment and conservation [42], 
this can only be true if the right mix of species were used. In the case of Effan Forest Reserve, where only Gmelina arborea was used, plantation establishment of this kind does not represent true enrichment planting, and might pose serious threat to conservation since most of the valuable indigenous species might have been destroyed in the process. In the same vein, charcoal production and transportations in the state are also regulated with permissions given by the same agents. All these have taken tolls on the originality of Effan Forest Reserve as evident in our findings. However, it is improbable to think that exotic tree plantations under any guise would replace indigenous-species filled forests and perform all the ecological functions of the latter. Nonetheless, we also found out that incursion into the plantation is on the way as many coppices are already surfacing from previously-logged Gmelina arborea, and checking the record; government has issued no circular supporting exploitation in the state. Our field observation does not reflect the current ban on timber exploitation and charcoal production in the state. It is very possible to actually regenerate a forest in the area without destroying the original composition, if not for other considerations. In Kwara State, natural regeneration is very potent considering the rapid growth rates and spread of many native tree species, especially Pterocarpus erinaceus and Vitellaria paradoxa $[43,44,45]$.

Other reasons for deforestation in the area were the perceived higher fertility and suitability of the reserve land for farming. Farmers have encroached the area for cultivation of grains and tubers in the last three decades. This agrees with Miranda et al. [46], who noted that areas with more suitable environmental conditions present a lower proportion of native forest cover, due to intrusion by farmers, particularly in the developing tropics. This may explain the prevalence of nomads and rice farmers in the area for suitable swamps for rice production. The activities of herders also severely 
impacted on primary and secondary forest as they are sufficient to constitute the first stage of deforestation, which is forest fragmentation. However, the less-accessible zones were least-disturbed, or too marginal to support agricultural activities, hence may retain good forest cover. This is true in the study area as the patches of natural forest left are found only along Effan River and its tributaries, which are currently impenetrable for the illegal operators, particularly loggers and charcoal producers. The surviving forests are mostly-concentrated along the riparian stretch.

\section{Summary}

The study has shown that tree diversity and richness in Effan Forest Reserve were negatively impacted by serial conversations of natural forests to monoculture plantation of exotic Gmelina arborea and farmland, which were not in existence before 1987, although no diversity assessment was conducted before that year, the State Forestry Report indicated that the reserve contained many valuable indigenous tree species like Ficus mucuso, Blighia sapida, Bridelia micrantha, Dialium guineense, Khaya senegalensis, Khaya ivorensis and Pterocarpus soyauxii earlier recorded before 1987. Unsustainable practices and compromise have birthed illegal land-use types, especially farming and charcoal production, which fragmented the forests and subsequently lead to eventual deforestation. The emergence of other land uses further worsened forest conditions since non-forest uses conflicted with the original objective of management. Over the 32-year period, the land use and cover of the area changed rapidly, and significantly with negative consequences on natural forest cover, losing 50.3\% in extent at an annual rate of $1.6 \%$ (12.66 ha). There were however, increases in plantation featuring only Gmelina arborea, a development that 
is inimical to ecological diversity, with negative socio-economic implications for the surrounding communities, who were, hitherto, dependent on natural forest resources. Meanwhile plantation increased from 25.4 to $50.7 \%$ within the period.

Major drivers of forest degradation in the area include illegal timber exploitation, unsustainable charcoal production and overgrazing. Based on the findings of this study, it is therefore recommended that forestry department, particularly forest guards, should step up actions in the reserved area to prevent further encroachment by unauthorized persons, especially herdsmen, farmers and charcoal producers so as to prevent further losses in forest extent. We also suggest that indiscriminate conversion to plantation of exotic tree species should be discouraged; instead enrichment planting should be carried out in areas considered to be depleted. This should involve outrightuse of indigenous tree species for greater ecological and socio-economic benefits. Ranching for livestock especially cattle, should also be considered to prevent further forest management conflicts in the state. Stakeholders directly involved in implementing afforestation programmes should endeavour to include local participation in their management plan. This will also give the surrounding communities some sense of belongings, and consequently offers some measure of security for the reserve. We observed that the patches of natural forests remaining in the reserve were riparian that offer protections to the Effan River and tributaries, and these relics thrive simply because of inaccessibility to the areas. However, strict protection measures need to be implemented around the riparian stretch to avert imminent loss of the forest, as signs of drains are already advancing towards the riparian. 
Authors Contribution: Conceptualization, A.A.A,; Methodology, A.AA. and F.M.O.; Software, A.A.A.; Validation, A.A.A.; Formal Analysis, A.A.A. and F.M.O., Investigation, A.A.A. and F.M.O.; Resources, A.A.A. and F.M.O.; Writing - Original Draft Preparation, A.A.A. and F.M.O.; Review and Editing, A.A.A. Both authors have read and agreed to the published version of the manuscript.

\section{Acknowledgements}

Authors appreciate the permission granted by the Department of Forestry, Ministry of Environment, Kwara State, Nigeria to conduct a non-destructive study in the reserve.

\section{References}

1. WWF. Draw the line, Annual Review, Gland, Switzerland, 2013, 44pp.

2. United Nations Department of Economic and Social Affairs, United Nations Forum on Forests Secretariat. The Global Forest Goals Report, 2021. 114pp.

3. EU. Forest biodiversity as a challenge and opportunity for climate change adaptation and mitigation. Presidency background paper presented at the Informal Meeting of EU Environment Ministers, 2008.

4. Adeyemi, A.A.; Jimoh, S.O.; Stem distributions and height-diameter allometries for two species of Irvingiaceae (Exell and Mendonça) in a tropical moist forest of southern Nigeria. Nigerian Journal of Agriculture, Food and Environment, 2013, 9(4), 25-36.

5. Adeyemi, A.A.; Ibe, A.E.; Okedimma, F.C. Evaluation of Tree Species Diversity in Okwangwo Forest, Cross River State, Nigeria. Journal of Research in Forestry, Wildlife and Environment, 2015, 7(2), 36-53. 
6. Boletta, P.E.; Ravelo, A.C.; Planchuelo, A.M.; Grilli, M. Assessing deforestation in the Argentine Chaco. Forest Ecology and Management, 2006, 228, 108-114.

7. Vásquez-Grandón, A.; Donoso, P.J.; Gerding, V. Forest Degradation: When Is a Forest Degraded? Forests, 2018, 9, 726-738.

8. Abubakar, A.; Abdulkadir, A.; Jibrin, A.; Abubakar, R.B. An Appraisal of Forest Degradation and Carbon Sequestration of Effan Forest Reserve Kwara State. Global Journal of Science Frontier Research, 2014, 14, 57-65.

9. Aro, J.K.; Daramola, E.L.; Daramola, J. An Assessment of the Impact of Deforestation on Climate Change: Case Study of Ilorin, Kwara State, Paper Presented at $56^{\text {th }}$ Annual Conference of Association of Nigeria Geographers, at Osun State University, Nigeria, 2015. Pp. 1-17.

10. Ogunwale, A.O. Deforestation and Greening the Nigerian Environment. International Conference on African Development Issues (CU-ICADI) 2015: Renewable Energy Track, 2015, Pp. 212-219.

11. Maitima, J.M.; Olson, J.M.; Mugatha, S.M.; Mugisha, S.; Mutie, I.T. Land Use Changes, Impacts and Options for Sustaining Productivity and Livelihoods in the Basin of Lake Victoria. Journal of Sustainable Development in Africa, 2010, 12(3), 189-206.

12. Alawamy, J.S.; Balasundram, S.K.; Hanif, A.H.M.; Sung, C.T.B. Detecting and Analyzing Land Use and Land Cover Changes in the Region of Al-Jabal Al-Akhdar, Libya Using Time-Series Landsat Data from 1985 to $2017 . \quad$ Sustainability, 2020, 12, 4490, doi: 10.3390/su12114490.

13. Worku, M.; Deribew, S. The Cause of Land Use Change and Effect of the Change on Crop Yield in Case of Azezo Tekle Haymanot Kebele. Journal of Agricultural Science and Food Research, 2018, 9(1), 212-219. 
14. UNFCCC. Land use, Land-use change and forestry, 2007.

15. Kwara State Ministry of Environment and Forestry. Annual Report. State Secretariat, Ilorin, 2017.

16. FAO. Global Forest Resources Assessment 2010. Main report, FAO Forestry Paper 163: Rome, Italy, 2010.

17. Azare, I.M.; Abdullahi, M.S.; Adebayo, A.A.; Dantata, I.J.; Duala, T. Deforestation, Desert Encroachment, Climate Change and Agricultural Production in the SudanoSahelian Region of Nigeria. Journal of Applied Science and Environmental Management, 2020, 24(1), 127-132.

18. Adisa, A.L.; Adekoya, J.A. Assessment of pollution by heavy metals in sediments of river Oyi and its tributary, southwestern Nigeria. Ife Journal of Science, 2016, 18(4), $871-885$.

19. Bello, A.; Makinde, V. Delineation of the aquifer in the South-Western part of the Nupe Basin, Kwara State, Nigeria. Journal of American Science 2007, 3(2), 36-44.

20. Oriola, E.; Chibuike, C. Flood risk analysis of Edu local government area (Kwara State, Nigeria). Sustainability 2016, 3(9), 106-116.

21. Margalef, D.R. Information Theory in Ecology. General System Bulletin 3, 1958, Pp. $36-71$.

22. Harris, P.M.; Ventura, S.J. The Integration of Geographic Data with Remotely Sensed Imagery to Improve Classification in an Urban Area. Photogrammetric Engineering and Remote Sensing 1995, 61, 993-998.

23. Liu, C.; Frazier, P.; Kumar, L. Comparative assessment of the measures of thematic classification accuracy. Remote Sensing of Environment 2007, 107, 606-616.

24. Enaruvbe, G.O.; Atedhor, G.O. Spatial Analysis of Agricultural Landuse Change in Asaba, Southern Nigeria. Ife Journal of Science 2015, 17(1), 65-74. 
25. Rwanga, S.S.; Ndambuki, J.M. Accuracy Assessment of Land Use/Land Cover Classification Using Remote Sensing and GIS. International Journal of Geosciences 2017, 8: 611-622.

26. Adeyemi, A.A.; Ibrahim, T.M. Spatiotemporal Analysis of Land-use and Land-cover Changes in Kainji Lake National Park. Forestist 2020, 70(2), 105-115.

27. Rudolf V.H.W., Lafferty K.D. Stage structure alters how complexity affects stability of ecological networks. Ecology Letters 2011, 14, 75-79.

28. Rao, M.; Larsen, T. Ecological Consequences of Extinction. Lessons in Conservation 2010, $325-53$.

29. Symstad, A.J.; Tilman, D.; Willson, J.; Knops, J.M.H. Species Loss and Ecosystem Functioning: Effects of Species Identity and Community Composition. Oikos 1998, 81(2), 389-397.

30. Von Hellermann, P. Things Fall Apart? Management, Environment and Taungya Farming in Edo State, Southern Nigeria. Africa 2007, 77(3): 371-392.

31. Isese, M.O.O. Impacts of Deforestation on the Loss of Biodiversity. International Journal of Forestry \& Plantation 2019, 1(2), 14-20.

32. Anyanwu, J.C.; Amaku, G.E.; Izunobil, C.; Egbuawai, O.; Onwuagba, S.M. Impact of deforestation on biodiversity in Anambra State,Nigeria. International Journal of Ecology and Ecosolution 2016, 3(3), 40-44.

33. Vedeld, P.; Angelsen, A.; Sjaastad, E.; Berg, G.B. Counting on the Environment: Forest Income and the Rural Poor, in Environmental Economics; The World Bank Environment Department: Washington DC, USA. 2004, 114pp.

34. WWF. Forest Conversion. WWF's Position Paper. WWF Forests Programme: Grand, Switzerland, 2008, 2pp. 
35. Suleiman, R.M.; Sawyerr, H.O.; Adio, A.; Salako, G. Spatial variation in diversity of woody vegetation species within Kwara State University Maletecampus, Kwara, Nigeria. International Journal of Biodiversity and Conservation 2018, 10(10), 419431.

36. FAO. State of the World's Forests: Forests and Agriculture: Land-use Challenges and Opportunities. Food and Agricultural Organization of the United Nations: Rome, Italy, 2016, 126pp.

37. Akinsanmi, F.A.; Akintunde, S.P. Analysis of Carbon Sequestration Potential of Tree Species in Agba Forest Reserve, Ilorin, Kwara State. Proceedings of the $38^{\text {th }}$ Annual Conference of the Forestry Association of Nigeria (FAN). Mangroves and Wetland of Sub-Saharan Africa: Potential for Sustainable Livelihood and Development, 2016, Pp. 653-662.

38. Ikyaagba, E.T. Plant Biodiversity and Ethnobotanical Potential of University of Agriculture Makurdi Wildlife Park and Ikwe Game Reserves, Igbo Benue State Nigeria. Unpublished Dissertation in the Department of Forest Resources Management University of Ibadan, Ibadan Nigeria, 2008, 123pp.

39. Fasona, M.; Adeonipekun, P.A.; Agboola, O.; Akintuyi A.; Bello, A.; Ogundipe, O.; Soneye, A.; Omojola, A. Drivers of Deforestation and Land-Use Change in Southwest Nigeria. In: Leal Filho W. (eds) Handbook of Climate Change Resilience, 2018. https://doi.org/10.1007/978-3-319-71025-9_139-1.

40. Duguma, L.A.; Atela, J.; Minang, P.A.; Ayana, A.N.; Gizachew, B.; Nzyoka, J.M.; Bernard, F. Deforestation and Forest Degradation as an Environmental Behavior: Unpacking Realities Shaping Community Actions. Land 2019, 8(2), 2642. 
41. Wajim, J. Impacts of Deforestation on Socio-Economic Development and Environment in Nigeria. The International Journal of Social Sciences and Humanities Invention 2020, 7(03), 5852-5863.

42. Miranda, A.; Altamirano, A.; Cayuela, L.; Antonio, L.; Gonzalez, M. Native forest loss in the Chilean biodiversity hotspot: revealing the evidence. Regional Environmental Change 2017, 17, 285-297.

43. Aderibigbe, E.J.; Folarin, O.O.; Ogunkunle, C.O.; Oladele, F.A. Eco-distribution of Vitellaria paradoxa (G.F. Gaertn) in Kwara State, Nigeria. Notulae Scientia Biologicae 2017, 9(4), 503-507.

44. Animasaun, D.A.; Oyedeji, S.; Olorunmaiye, K.S.; Azeez, M.A.; Tijani, I.A.; Morakinyo, J.A. Morpho-chemical divergence and fatty acid profile of shea tree seeds (Vitellaria paradoxa) collected from different locations in Kwara State, Nigeria. Acta Botanica Croatia 2019, 78(1), 17-24.

45. Adeyemi, A.A.; Taofeek, H.T. Tree Structural Diversity and Yield Prediction Models for Tree Species in Old Oyo National Park, Nigeria. American Journal of Plant Biology 2020, 5(2), 11-20.

46. Miranda, A.; Altamirano, A.; Cayuela, L.; Pincheira, F.; Lara, A. Different times, same story: native forest loss and landscape homogenization in three physiographical areas of south-central of Chile. Applied Geography 2015, 60, 20-28. 